\title{
MORAL ECONOMY AND MAORI FISHERIES
}

\author{
Fiona McCormack
}

\begin{abstract}
In this article I argue that the separation of commercial and customary fishing, which was a result of the 1992 Treaty of Waitangi Fisheries Settlement Act, denies their essential integration in the practices of small-scale fishers across time and space. Theorists who have analysed the moral economy and petty commodity production invariably conclude that commercial production (for money and/or profit) and customary production (for subsistence and the fulfilment of cultural activities and obligations) exist on a continuum and that both are indeed necessary for the survival of small-scale producers. The definition of customary activity as the absence of monetary transactions is not consistent with either international legal decisions, or with the social reality of small-scale Maori fishers, who operate in mixed economies, sometimes moral, sometimes capitalist, and exchange fish in much the same manner, sometimes in order to achieve a balance and sometimes for profit.
\end{abstract}

\section{INTRODUCTION}

The progressive alienation of Maori ${ }^{1}$ fisheries over time had its origins in many developments such as the denial of Maori aboriginal rights and title; the contradictions in Treaty Settlement packages; the imposition of formal fishery management regimes; the privatisation of the fisheries resource and subsequent dispossession of small-scale fishers and the Crown's historic assumption of ownership of the foreshore and seabed area. This article concentrates on one, albeit fundamental, characteristic of this process; the impact of the 1992 Treaty of Waitangi Fisheries Settlement Act and the creation of a legislative distinction between commercial and non-commercial, or customary Maori fisheries. This situation is defined by the current legal prohibition on Maori small-scale fishers (who do not hold individual transferable quotas or commercial fishing quotas) from earning a livelihood from their work. 
The distinction between commercial and non-commercial Maori fishing activity is highly problematic and may be illustrated by a consideration of the concept of the moral economy. E. P. Thompson was perhaps the first academic to employ the concept of 'moral economy' as an analytical tool. Thompson adopted an anti-capitalist usage of the moral economy in his analysis of the food riots in late eighteenth century England. ${ }^{2}$ The notion of the moral economy arose in the context of confrontations in the market place over access and entitlement to essential food items and signified 'a last desperate effort to re-impose the old paternalist moral economy as against the economy of the free market' (1991:337).

The 'Moral Economy' refers to a type of economy where the relations of production are based on kinship and in which the mechanisms of redistribution tend to play a levelling role amongst the members of a given community. The premise is that in times of hardship the basic items of consumption necessary for survival will be accessible to those in need. Thompson's seminal work is informative for three reasons: first, it highlights the interconnections between the emergence of the market economy and private property rights; second, it notes how the role of culture is centralised in the market place; and thirdly, it emphasises the dynamic role of tradition as a tool employed to challenge situations of deprivation.

James Scott, building on the earlier work of writers such as Thompson, Wolf, Chaynov and Polanyi argues that the essential feature of the peasant ${ }^{3}$ economy is the moral content of the subsistence ethic: that there is a close interconnection in the peasant mind between economic calculation and moral norms. The peasant household, as described by Scott, is one which normally revolves around avoiding failures that might ruin it rather than being one which is characterised by risk-taking. Briefly put, Scott argues that peasants are typically people living close to the margins of survival and this ongoing shortage gave rise to a 'subsistence ethic'. This ethic resulted in social arrangements such as:

...patterns of reciprocity, forced generosity, communal land, and work-sharing [which] helped to even out the inevitable troughs in a family's resources which might otherwise have thrown them below subsistence

(Scott, 1976:3). 
The end result of these social arrangements was to ensure that all within the community were entitled to a living from the available resources.

It is the absence of the threat of individual starvation which makes primitive society, in a sense, more humane than market economy, and at the same time less economic

(Polanyi, 1957 in Scott 1976:5).

Thus the desire for subsistence security arises out of the peasant economic system and was experienced socially as a conglomeration of moral rights or expectations. Conversely, when this moral standard was threatened or ignored, resentment and resistance could be expected. This is so because not only is the economic sustainability of a community under attack but also its social system. This violation of a way of life inspires and shapes the understanding peasants have of exploitation and fuels much of their collective action.

Scott further shows 'how the central economic and political transformations of the colonial era served to systematically violate the peasantry's vision of social equity' (1976:4). Colonisation worked to replace what were, on the whole, reciprocally based beneficial patron-client ties between elites and peasants with more impersonal and inflexible contractual relationships. According to Scott, peasants have historically reacted by resistance aimed primarily at restoring a pre-existing and essentially moral state of affairs.

As in the case of Thompson, Scott's work highlights the role of tradition and culture in situations of oppression and deprivation. Rather than appearing to be locked into an unchanging world, incapable of comprehending the forces of development or modernisation and clinging tenaciously to their traditions as the rest of the world moves on, Scott's peasants use tradition in a dynamic way to challenge the erosion of their way of life in both the economic and social spheres. Tradition is employed to counter the new class and property systems that capitalism seeks to establish and which inevitably lead to greater and permanent inequalities of wealth and loss of control over subsistence resources.

However, Scott's work may be challenged on the grounds that it implies a dichotomy between the moral economy, based solely on activities to ensure subsistence, and the capitalist economy, based on the maximisation of returns, or profit. This dichotomy results in the reduction of the economic behaviour of peasants to the former sphere and identifies modern capitalist economic activity solely with the latter. At the same time both categories effectively isolate 
economic activity from other aspects of social life. Appadurai (1986) argues that in order to overcome dichotomies implied in the categorisation of economic and non-economic action, both the calculative dimension present in all forms of exchange and the neglected cultural dimension of market exchanges must be recognised.

In his observations on Western Ireland in the 1990s Salazar finds that while farmers participate in the individualistic and profit-maximising ethos characteristic of all capitalist societies, there is still a substantial sphere in which noncommodity transactions take place. According to Salazar, 'There is a sphere of transactions or a sphere of human behaviour in general terms, that cannot be subsumed either to an individualistic profit-maximising rationality, or to a collective normative logic' (1996:136). Further,

It is in this domain of economic relations that neither the moral economy nor the political economy approach provides, in my view, an entirely satisfactory perspective. Yet, at the same time, both of them hint at important attributes of that sphere of no commodity transactions

(ibid 1996: 126).

Perhaps the major key to non-capitalist economic relations is that they simultaneously involve a norm of generalised reciprocity and an element of strategic manoeuvring, with the weighting of the balance between the two varying, dependant upon the prevailing social relations and the context in which the transaction takes place. As Salazar argues, 'a moral obligation cannot be too drastically isolated from its material implications' (1996: 131).

Gift-exchange in the moral economy is multifaceted. It is not a phenomenon that can be categorised as a form of alms nor defined as being non-commercially motivated. Neither can it be seen solely as a way of procuring gains; as a means to create a relationship of obligation or the establishment of a reciprocal exchange relationship. Gift exchange includes all of these dimensions and is simultaneously characterised by altruistic and pecuniary motives. Indeed, the fact that it may include these apparently opposed characteristics is what makes the very action of gift-giving an essentially human attribute.

It is possible to list the important qualities of the concept 'the moral economy' as follows: 
- Distribution plays a levelling role. That is, it emphasises equality amongst members of a given community. This implies that in times of scarcity the basic items of consumption necessary for survival are accessible to those in need.

- Implicit obligations and duties constitute a traditional or cultural right. Hence threats to the functioning of a moral economy disrupt socioeconomic systems and may lead to collective action.

- Economic relations simultaneously involve a norm of generalised reciprocity and an element of strategic manoeuvring.

- The degree of moral obligation or expected reciprocity with which a specific gift is given, or service offered, determines where it is located on the scale between the extremes of purely contractual and purely moral relationships.

- Reciprocity arises fundamentally from pre-existing social relations rather than expectations or non expectations of a return or counter-service.

- Moral economies co-exist alongside capitalist markets and relations of production.

The co-existence of moral economies alongside capitalist markets, and the ongoing existence of traditional social relations, is further elucidated in the literature on petty commodity production ( $\mathrm{PCP}){ }^{4} \mathrm{PCP}$ theorists stress the existence of complex linkages and dependent relationships between informal and formal sectors of the economy and production and distribution systems. PCP analysts identify more than one mode of production in any given economy. For instance in an urban sector, modes of production include the capitalist sector which is deeply integrated into an international economy and 'a variety of precapitalist modes each more or less transformed through its relation with the former' (Moser, 1978: 1957).

Long and Richardson (1978) describe petty commodity producers as those workers involved in both traditional and modern artisan production, peasant agriculture and other services such as small-scale trade and transport. Presumably small-scale fishers can also be included in this category. These petty commodity forms are characteristically small-scale, linked to commodity exchange and 'relatively independent in terms of the ownership and control of the means of production with little separation between capital and labour' (Long and Richardson, 1978:185). Resources are mobilised using social networks and production and consumption activities are interrelated. Thus, petty commodity producers work simultaneously within a moral-economy, where what is produced is both for subsistence and reciprocal exchange purposes and a capitalist economy where, albeit located in a subordinate position, ex- 
change is conducted ostensibly for profit. What is noteworthy is that although involved in a capitalist economy and hence the commodification of goods and labour, petty producers maintain traditional production activities and traditional relations of production. Cook and Binford (1990) remark on the historic persistence and universality of petty producers who produce products simultaneously for direct consumption and for market exchange. These petty producers have maintained land and labour power, and kinship and community based social relations, despite being partially engaged in production for a capitalist market '...it is clear that small-scale commodity production thrives in the capitalist world economy, not only in the "periphery" but also in the "core"'(1990:1). Thus the universal proliferation of petty commodity producers coincided with the increasing expansion of capitalism.

THE CASE OF MAORI CUSTOMARY FISHERIES: BRIEF BACKGROUND

The 1992 Treaty of Waitangi Fisheries Settlement Act was arguably the formalisation of a number of preceding fisheries acts which had had the effect of excluding a large proportion of Maori small-scale fishers from the commercial sector. ${ }^{5}$ Additionally, it created an artificial legislative distinction between Maori commercial and customary fisheries; ${ }^{6}$ Section 10 of the Act provided that regulations be developed to cover the customary aspect of Maori fishing. These were to be developed in conjunction with Maori representatives and the ensuing discussions between Crown and Maori ${ }^{7}$ were a long, drawn-out and essentially contested process. By 1998 no regulations were forthcoming. During this time section 27 of the Amateur Fisheries Act 1986 continued to govern Maori customary take. Section 27 was amended a number of times during this period so that the conditions under which Maori could partake in customary fishing became increasingly restricted. Fundamental to the tightening of regulations was the removal of any loophole that enabled Maori to sell fish for cash. In late 1998, then Minister of Fisheries, John Luxton announced that customary regulations would be in place by the New Year. This final stage in the process involved a hurried round of consultations and arguably the imposition of, at best, partially mandated regulations.

In 1998 the Fisheries (South Island Customary Fishery) Regulations were enacted and on the first day in February 1999, the Fisheries (Kaimoana Customary Fishing) Regulations 1998 came into force in the North Island of New Zealand. ${ }^{8}$ Regulation 27 was to continue to determine fishing activity in areas of New Zealand where Customary Fishing Regulations were not yet formalised (to be formalised the process requires, amongst other things, a rohe to be declared and Kaitiaki appointed). Once customary Fishing Regulations 
covered the whole country, Regulation 27 would no longer be used for any salt-water fisheries.

\section{CUSTOMARY FISHERIES: LEGISLATION}

At present Maori customary fisheries are governed by three sets of legislation: the Kaimoana Customary Fishing Regulations 1998 together with the Fisheries (South Island Customary Fishing) Regulations 1998. In addition there is also Regulation 27 of the Fisheries (Amateur Fishing) Regulations to consider and finally, Section 186A of the Fisheries Act 1996. ${ }^{9}$ I will now discuss these three separate groups of legislation in more detail.

THE KAIMOANA CUSTOMARY FISHING REGULATIONS 1998 AND THE FISHERIES (SOUTH ISLAND CUSTOMARY FISHING) REGULATIONS 1998

The Customary Fishing regulations can only be applied by groups which can prove conclusively that they are tangata whenua. The regulations make provision for that group to appoint kaitiaki or guardians to manage customary fishing in the area. The main thrust of the regulations concerns the procedure to be followed to allow for 'customary food gathering. The Minister of Fisheries confirms the appointment of the kaitiaki and authorised kaitiaki become the only people who can permit customary non-commercial fishing in their area. They do not have any standing outside their region of legal authorisation.

Kaitiaki must report their activities to tangata whenua regularly and report the quantities of fish that they are authorising to the Ministry of Fisheries. Permits must be made available to Fisheries Offices on request and fishing must be conducted in a sustainable manner. Authorisations issued by kaitiaki must be in writing and must, according to regulation 11 subclause (3), specify:

- The date(s) when fishing is to occur;

- Who will be taking the fish;

- Quantity and size limit of each species to be caught;

- The fishing method for each species;

- The area where fishing is to occur;

- The purpose and venue for which the fish are needed;

- Any other matters the Tangata Kaitiaki/Tiaki considers necessary, including what to do with any bycatch.

Under regulation 16 any Tangata Kaitiaki/Tiaki may prepare a management plan or strategy for the area/rohe moana (sea territory of hapu or iwi) for which 
that Tangata Tiaki has authority. Subclause (2) stipulates:

When a plan is prepared by a Tangata kaitiaki/Tiaki and that plan is agreed to be authorised by the tangata whenua of the area/rohe moana for which the Tangata kaitiaki/Tiaki was appointed, the plan:

(a) May be treated as a planning document recognised by an iwi authority for the purposes of the Resource Management Act 1991, if it meets the requirements of that Act;

(b) Must be taken into account by the Minister for the purposes of section 10(b) of the Treaty of Waitangi (Fisheries Claims) Settlement Act 1992.

Under the Fisheries Act, 1996, the plans can also be used for the development of sustainability measures for those fisheries in the rohe of the tangata whenua. Regulation 16 stipulates that any sustainable management regime proposed by kaitiaki and supported by tangata whenua needs to be approved through the requirements of the Resource Management Act 1991. It must do this before it may be taken into account by the Minister of Fisheries as a strategy to 'develop policies to help recognize use and management practices of Maori in the exercise of non-commercial fishing rights' (Settlement Act, 1992, Section 1ob (ii)). It is noteworthy that fishery practices recommended by Maori within a hapu or iwi's rohe are subject to a process of outside approval before being put into practice as a sustainable management regime. Indeed, the provision that the Minister of Fisheries is merely required to 'take into account' such plans is a considerably weaker stipulation than, for instance, the requirement to 'give effect to' Iwi Planning Documents.

Regulation 18 enables Tangata Kaitiaki/Tiaki to apply for a mataitai reserve in any part of their rohe moana.

Mataitai reserves are areas where the tangata whenua manage all non-commercial fishing by making bylaws. The bylaws must apply equally to all individuals. Mataitai reserves may only be applied for where there are traditional fishing grounds and these locations must be areas of special significance to the tangata whenua. In general there is no commercial fishing within mataitai reserves

(Ministry of Fisheries, n.d.).

Bylaws created in mataitai reserves refer to restrictions or prohibitions relating to: 
a. The species, aquatic life, or seaweed that may be taken;

b. The quantity of each species that may be taken;

c. Size limits relating to each species to be taken;

d. The method by which each species may be taken;

e. The area or areas in which species may be taken;

f. Any other matters the Tangata Kaitiaki/Tiaki considers necessary for the sustainable utilisation of fisheries resources in that mataitai reserve

(Regulation 28 [2]).

Establishing a mataitai reserve is contingent on the discretion of the Minister of Fisheries, and must take account of submissions and consultations with the local community (regulations 19 and 20). Mataitai reserves must be 'of a size appropriate to effective management by tangata whenua' (regulation 23:c) and must not affect commercial fishing (regulation 23:e [ii] and [iii]).

North Island regulations require that an overall rohe moana be established prior to a notification for a mataitai reserve being accepted by the Ministry of Fisheries. The actual process of establishing a reserve is arduous 'because [of] the opportunity for objections to be received from recreational, commercial [interests] and local residents also available.. ${ }^{10}$

\section{REGULATION 27 OF THE FISHERIES (AMATEUR FISHING)}

Regulation 27 continues to determine fishing activity in areas of New Zealand where Customary Fishing Regulations are not yet formalised. Once customary Fishing Regulations cover the whole country, Regulation 27 will no longer be used for any salt-water fisheries, but will continue to be the only mechanism for customary fishing of freshwater fish species covered by the Quota Management System (QMS) (e.g. eels and lamprey).

The Ministry of Fisheries further amended the regulation in April 2003, citing the following reasons:

Because of the ability of a number of organisations to claim tangata whenua status in an area and the limitation on accountability in the regulations, they have proved to be susceptible to misuse by a small minority of illegal fishers who have sought to use those Regulation 27 defences when caught poaching. This has led to a significant tightening of the rules in 2003

(Ministry of Fisheries, n.d.). 
'Significant tightening' refers, among other things, to the stipulation that 'fishers must not under any circumstances, sell, exchange or trade any of the fish taken under the authorization for money or other items'. This is a highly restrictive interpretation of what 'customary activity' implies and signifies a growing chasm between what is defined as commercial and what is defined as customary or traditional. ${ }^{11}$ The 'tightenings' additionally include:

- All fishing gear used (e.g. buoy, float) must be marked with the authorisation number;

- No fishing can take place inside an area notified under the Customary Fishing Regulations;

- Written authorisation must accompany any fish taken. The authorisation must state:

»Who can take the fish (all harvesters)

"Which species can be taken

» Maximum number of each species that can be taken (number or greenweight)

" The area where the fish can be taken from

"The place at which the fish must be landed

"The dates and time within a 48 hour period on which fishing can occur

"The hui or tangi, and the place, where the fish will be used

" The signature and name of the person who gave the authorisation to take the fish.

\section{SECTION 186A OF THE FISHERIES ACT 1996}

Section 186A applies to areas outside of mataitai reserves and, it is asserted, provides a method 'for tangata whenua to manage commercial and recreational fishing' (Ministry of Fisheries, n.d.). Section 186A:

...allows the Minister of Fisheries to temporarily close an area to fishing, or to restrict a method of fishing, in order to provide for the use and management practices of tangata whenua in the exercise of their non-commercial fishing rights.

Temporary closures and method restrictions will give legal support to voluntary rahui which have always been used by tangata whenua to manage their fisheries.

(Ministry of Fisheries, n.d.). 
The establishment of legally enforceable closures and method restrictions, up to a maximum of two years, is contingent on the discretion of the Minister of Fisheries and subject to consultation with all those that have an interest in the fishery, including commercial, recreational, environmental, and local community interests as well as tangata whenua.

THE EFFECTS OF THE REGULATIONS TO DATE

The three sets of regulations described above are now in place and it is interesting to examine to what extent they have been successfully applied. According to the Ministry of Fisheries it 'does not have concerns about the Customary Fishing Regulations, which are working well', (Ministry of fisheries n.d.).

However, for a number of reasons this confidence in the efficacy of the regulations in practice seems to be somewhat misplaced. Firstly, no central Government organisation holds information about the number of currently existing Iwi Planning Documents concerned with fisheries. ${ }^{12}$ I contacted the thirteen regional councils in New Zealand and enquired about the status, under regulation 16 of the Customary Fisheries Regulations 1998, of Iwi Planning Documents. The responses from Regional Councils suggested that no such documents exist.

Secondly, as of October 2004 the South Island of New Zealand has four established mataitai reserves; two in Lyttleton Harbour, one at Rapaki Bay ${ }^{13}$ and another at Kokorourata (Port Levy). In addition there are applications for sites on the Mataura River near Gore, Waitutu near Riverton in Southland and one of the Mutton Bird Islands near Stewart Island. Only Rapaki currently has bylaws in place prohibiting the taking of stingray, paua and seaweeds. In the North Island two applications are being considered, one at Torree in Eastern Bay of Plenty and one in Northern Hawkes Bay. ${ }^{14}$

Thirdly, as of October 2004 five $\$ 186 \mathrm{~A}$ temporary closures are in effect in the North Island. These are located at Hicks Bay, Pukerua Bay, Mt Maunganui, Ohiwa Harbour and Western Coromandel Peninsula. One \$186B temporary closure (South Island fisheries waters) exists at Kaikoura-Wakatu Quay in the South Island. There was also a $\$ 186 \mathrm{~A}$ temporary closure put in place in 2000 at Tinopai (Kaipara Harbour) which prohibited commercial fishers from taking fish at Tinopai for two years. This temporary closure order was not renewed. Additionally in 2001 a two year $\$ 186$ A temporary closure prohibited shellfish harvesting at Eastern Beach (Manakau City). ${ }^{15}$ 
From the preceding evidence it appears that customary fisheries regulations are operating only on a very limited scale, given the non-existence of Iwi Planning Documents, and the paucity of established mataitai reserves and temporary closures. This would seem to contradict the Ministry of Fisheries statement that the regulations were 'working well'.

The impression of non-completion does not end here. I requested information from the Ministry regarding the replacement of Regulation 27 of the Fisheries (Amateur Fishing) Regulations 1986 with either the South Island Customary Fishing Regulations or the Kaimoana Customary Fishing Regulations. The reply is copied below:

Regulation 27 operates in the Christchurch area, top of South Island (Te Tau Ihu). In the North Island most areas operate on Reg 27 but there are a few areas that have changed over to the Kaimoana regulations - North of Napier, North of Gisborne, North of Opotiki - just small areas.

At this stage it is easier to say that most of the SI [South Island] operates under the South Island customary Regs [Regulations] and most of the NI [North Island] operates under Reg $27{ }^{16}$

Given that customary regulations were enacted in 1998/99 the lack of implementation is somewhat surprising. The reasons for the lack of uptake, according to the Ministry are:

There are a number of reasons but I guess the main one is that the regs [regulations] require boundaries to be declared (rohe) and kaitiaki to be appointed to these areas.

There are a further number of reasons why a number of iwi groups can't agree on boundaries some historical some relatively recent. MFish has recently received specific funding to assist with the implementation so we are hopeful that good progress can be made in the next while. ${ }^{17}$

This reasoning not only resonates of victim bashing but additionally demonstrates a misunderstanding of Maori geopolity. As one reviewer of this article noted: 
the issue of rohe is not as straightforward as defining boundaries. Rohe are not necessarily geographically discrete but are associated with a group of people. Accordingly, a people's rohe is not always contiguous and rohe may overlap. In addition, where boundaries are relevant (and this applies to most cases) the issue is bound up with Treaty claims. For instance Ngai Tahu's northern boundary was defined in their settlement act but later challenged by the northern neighbours during their claim and the issue is still unresolved ten years later. This is being used by токм as a reason for not settling commercial fisheries assets.

Alternatively, Margaret Mutu maintains that hapu and iwi are unwilling to implement the regulations as they effectively remove customary fishing practices from Maori control. Amongst Ngati Kahu, at least, the Kaimoana regulations are unacceptable as they essentially mean Ministerial control of Maori fisheries.

The Waitangi Tribunal in its 2004 Foreshore and Seabed report was extremely critical of the Customary Fisheries Regulations and expressed concern that the Foreshore and Seabed policy would be analogous to both the Resource Management Act and the customary fishing regulations which 'promised much but delivered little' (2004:122). The Tribunal described the customary fishing regulations as a regime which removed Maori property rights at law and replaced them with the right to participate in the decision-making process. It acknowledged the lack of official information on how the processes for customary fishing are working and observed that there is a lot of complaint about them from Maori (the low-level of uptake by hapu Maori was considered telling). The Tribunal wondered whether Maori interests would have been better served if they had retained legal rights to their customary fisheries instead of exchanging those for a process over which they had little control, and no funding for their participation (2004:117). Indeed this issue had been envisaged by McHugh in 1992 when he argued that it was unfortunate that customary fisheries were included under the Maori Fisheries Act 1989 in light of the legal breakthrough in the $1986 \mathrm{Te}$ Weehi case concerning aboriginal title. Prior to the case, courts had not recognised customary fishing rights except those conferred by statute. Treaty rights were considered bereft of any legal meaning and survived merely as moral claims against the honour of the crown. The 1989 and 1992 Acts no longer permitted the development of aboriginal title through the courts and instead, government approved regulations were to detail the nature and extent of Maori customary fishing rights. 
The Kaimoana Customary Fishing Regulations 1998 describe customary food gathering as:

The traditional rights confirmed by the Treaty of Waitangi and the Treaty of Waitangi (Fisheries Claims) Settlement Act 1992, being the taking of fish, aquatic life, or seaweed or managing of fisheries resources, for a purpose authorized by Tangata Kaitiaki/Tiaki, including koha, to the extent that such purpose is consistent with Tikanga Maori and is neither commercial in any way nor for pecuniary gain or trade

(emphasis added).

The reviewers of this article have emphasised that koha is much more structured than a simple 'gift' and that reciprocation is a fundamental component of the system. Williams and Robinson define koha as the giving of a gift that necessitates a reciprocal response.

For Maori, a gift is more than an object passed form one person to another. To start with, it may not be an object at all: giving one's time is comparable to giving money, goods, or services, or to granting a mandate (that is endorsing someone to act on your behalf). More fundamentally a gift makes a statement about place - the place of the giver and the place of the receiver. This clarifies and enhances the position and status of an individual with the Iwi and the wider community

(2004:2).

The incorporation of Maori words and concepts into legislation, for instance 'kaitiakitanga' in the Resource Management Act 1991, has been questioned by a number of commentators. Section 7 (a) of the Resource Management Act 1991 defines kaitiakitanga as 'the exercise of guardianship; and, in relation to a resource, includes the ethic of stewardship based on the nature of the resource itself'. This statutory definition is conceived of as limiting the concept and even degrading it (Solomon and Schofield 1992, Tomas 1994, Nuttall and Ritchie 1995 in McCormack 1997) and ignores extensive criticism by Maori during the drafting of the legislation. Kaitiakitanga is an essential principle of Maori society encapsulating the whole of Maori resource management regimes and 
supplying its own ethic and rules for human interaction with other natural resources. As such it is inextricably linked to the concepts of rangatiratanga, power and authority. This totalising conception is, within the context of the Act, reduced to the notion that it refers to several matters that persons exercising powers and function must have particular regard to. This seems both arbitrary and essentially constraining. Further, the manner of inclusion in the Resource Management Act 1991 creates the potential for non-Maori to claim this relationship and for the Environment Court to deny or seek comprehensive elucidation of the connection with regard to Maori. According to Minhinnick 'Only tangata whenua can be kaitiaki, can identify kaitiaki, and determine the form and structure of kaitiaki' (1989:4 in McCormack 1997).

The process by which the term 'koha' was included in the Customary Fisheries regulations is intimately bound up with court cases during which Maori fishers argued that they were fishing according to aboriginal title or Article two of the Treaty of Waitangi; that their right to fish without commercial quota was a customary right; that customary fishing was much more than supplying fish for hui and tangi ${ }^{18}$ and that the exchange of fish for other items, including money, was in keeping with the practice of koha. Arguably, in articulating their perceived rights Maori fishers were employing cultural practices and belief systems to challenge the commodification of the fishery resource.

For instance, in the (1997) Ministry of Agriculture and Fisheries $v$ Reed $y^{19}$ case, Reedy argued for his entitlement to take and distribute seafood in accordance with Maori custom. Reedy had set up a table in a fleamarket for the sale of Kina and Kahawai in pottles. The pottles were marked with 'Koha Nga Hinerupe' and did not display price tags (Hinerupe was the name of a meeting house for which Reedy was seeking rebuilding funds). A Maori witness in the case described koha as being similar to a European barter system. ${ }^{20}$ Judge McLean convicted Reedy, reasoning that:

Mr. Reedy's activity was clearly in the commercial arena. He was seeking money for the fish in a public setting in a public market. There is no legislative basis for Mr Reedy's claim to be entitled to sell fish under a customary fishing right... The ability for Maori to exercise a customary fishing right to obtain money for fish even where this may be for fundraising purposes, has been closed by the 1992 Settlement Act... ${ }^{21}$

In Ministry of Agriculture and Fisheries v John Samuel Ututaonga and Gael Alecia Hona22 the court examined the meaning of 'koha'. Ututaonga was sell- 
ing fish for a trust at a marae in January 1998. He was operating from a trailer with ice buckets and bins and the advertisement on the side of the trailer read 'koha priced fish'. In his decision Judge T Everitt reasoned:

I use the word buy in a neutral sense in that the advertising on the side of the trailer said Koha Priced Fish and the reasons advanced relates to koha, that some people paid in money; some $\$ 48$-odd was found in a bucket... But if someone wanted to give some potatoes, vegetables or fruit in exchange, a $\$ 5$ bag of Kerikeri oranges for example, that would have been acceptable....Mr Ututaonga said. ...that they were not giving the fish away for nothing because there had to be some covering of at least the petrol cost of the outboard motor... No doubt some needy person may well have been given a fish

$(1998: 3) \cdot{ }^{23}$

The issue before the Court was whether or not the fish was sold, that is whether the sale under a koha system fell within the definition of 'sale'. Everitt believed that it did if any benefit was received and that 'sale' could also cover bartering such that if the fish was exchanged for vegetables or fruit it fell within the definition.

...thus you can say that the koha system as I understand it operating on the day 20 January fell within that very method of disposition for valuable consideration, the valuable consideration being that $\mathrm{Mr}$ Ututaonga would be reimbursed for his petrol money

$(1998: 9) \cdot{ }^{24}$

Everitt went on to state

... a koha in the sense of the word for a gift taken from the Williams Maori Dictionary does not involve money. It seems that things may have developed since the time that the Reverend Williams wrote his dictionary, in that koha has taken upon meanings other than a mere gift. Although it is not entirely clear, it is not for me to say how Maori people define concepts and terms which they use (1998:10). ${ }^{25}$

Contrary to this last statement, Everitt through his decision defined koha for all intents and purposes as a 'gift' requiring no reciprocation and hence having no implications for social exchange networks. 
In Ministry of Fisheries v John Hikuwai (June, 1999), J Rushton deliberated:

It appears to this Court that the word koha has a number of meanings attributed to it ranging from an unsolicited gift given from the heart to an exchange for money....It would be inappropriate for this Court to endeavour to define or redefine the word koha. What is important is the nature of the transaction and whether or not it falls within the definition of sale set out in the relevant legislation. The fact that the expression koha may be used for the transaction does not by itself invest that transaction with some form of magic which exempts it from the legislation.

From the evidence, there was to be an exchange for money or monies worth in at least some of the situations, to pay for the running of the boat and the wages. This clearly fell within the definition of sale

$(1999: 46-47){ }^{26}$

Again, despite the 'inappropriateness' of his Court defining Maori concepts, Rushton's decision effectively excludes exchange, including the exchange of money, goods and services, as a component of koha.

In the same case, the defendant John Hikuwai described the customary fishing regulations as doing little more than maintaining an illusion that Maori customary fishing rights were ongoing:

According to Ministry of Fisheries regulations each marae nominates a kaitiaki which is a guardian and holds a permit book and if anybody wants to gather kaimoana for hui or tangi they apply to this kaitiaki, they must specify the amount and the type of species they intend to collect, he supplies them with the signed document and they go and collect it...in my experience living in these areas [the regulations are] quite impossible, impractical and impossible. To start with there is no provisions for the running of the equipment and the vessels to carry out this operation so therefore the socalled available non quota customary right all goes into the regime, the fishing industry board, TAC [Total Allowable Catch], doesn't get collected.

It seems it is impossible even for donations in these maraes, including individuals to help with the ongoing running expenses of seafood gathering, what 
it leads to, is raping and pillaging of the very inshore kaimoana which you don't need a lot of equipment to gather.

...unless you are licensed, licensed to sell fish the legislation does not allow for the sale of any of the fish you might collect no matter how genuine your purpose...the fishermen genuinely helping out in the community, especially the Maori community and poverty stricken communities are definitely hamstrung

$(1999: 14-15){ }^{27}$

When asked whether koha could include money for expenses, John replied:

Absolutely. For example just very recently I attended a two day hui at Otara at Ngati Otara marae... and I saw numerous envelopes passed across to the Kaumatua that held cash that came in for koha

$(1999: 21){ }^{28}$

CANADIAN CASE LAW

Canadian courts appear to have a more progressive view of the meaning of commercial than their New Zealand counterparts. New Zealand case law has developed a strong distinction between commercial and non-commercial fishing or customary fishing where the latter is said to function 'not for pecuniary gain'. In contrast, Canadian case law indicates an awareness of subtleties in this area, and maintains that selling fish is feasible as an expression of an aboriginal right so long as the proceeds are used for a non-profit motive, such as to support the needs of the household. Hence, selling for subsistence is deemed appropriate. For example, in Van Der Peet ${ }^{29}$ the sale of ten salmon was at issue, the court stipulated that the rights claimed was not to fish commercially but the rights to exchange fish. L'Heureux-Dube reasoned that the purpose of an activity should be important to its definition:

...the purposes for which aboriginal activities are undertaken cannot and should not be strictly compartmentalized...such purposes should be viewed on a spectrum, with aboriginal activities undertaken solely for food, at one extreme, those directed to obtaining purely commercial profit, at the other extreme, and activities relating to livelihood, support and sustenance, at the center

(1996, para 192). 
This reasoning raises the possibility that the simple distinction in the New Zealand courts between commercial and non-commercial activities may be inappropriate and indeed may fail to comprehend the reality of Maori use of their fisheries.

The Crown's persistent rebuttal of the claim that customary fishing may involve the exchange of money, has culminated in the legal redefinition of koha, at least in the area of customary fishing, as an action that 'is neither commercial in any way nor [is] for pecuniary gain or trade', and this is said to be 'consistent with Tikanga Maori'. The use of Maori concepts in legislation is problematic, in that it renders culture static and reduces the totalising aspect of such concepts to narrow legal definitions. The incorporation of koha into customary fisheries legislation in a sense symbolises the rigid division of Maori commercial and customary fishing practices. The inclusion, in effect, reduces koha to a practice removed from socio-cultural, economic and political transactions and identifies it as a rather benign expression of 'alms-giving.' Culture thus becomes both non-material and non-traditional. Further, the problematic incorporation of koha in customary fishing regulations contains its own contradictions since koha in other contexts can include monetary payments and indeed is subject to taxation. ${ }^{30}$

\section{CONCLUSION}

The division of Maori fisheries into the distinct spheres of customary and commercial is incompatible with social reality, and has led to dissatisfaction among small-scale Maori fishers with both elements of the 1992 fisheries settlement package. Theorists who have analysed the moral economy and petty commodity production invariably conclude that commercial production (for money and /or profit) and customary production (for subsistence and the fulfilment of cultural activities and obligations) exist on a continuum and that both are indeed necessary for the survival of small-scale producers. There are fundamental differences between the exchange and distribution mechanisms that characterise the moral economy and the capitalist economy. In the moral economy, exchange is premised on the maintenance of a balance between giver and receiver and distribution is dependent on social relations. In the capitalist economy, exchange is based on the accumulation of capital or profit, and distribution is contingent on the market mechanism. Despite assertions to the contrary by the New Zealand government and legislature there is no legitimate distinction to be made between the commercial and customary dimensions of small-scale Maori fishing since the two co-exist wherever fishing takes place. Nor does this conjunction mean that small-scale Maori fishing is 
any less customary. This is so because the commercial element is not an end in itself but is simply a by-product of a trading relationship in which use value takes precedence over exchange value. This is what distinguishes this type of trading from capitalist market relationships based on exchange values. Further, as the literature on petty commodity production shows, small-scale producers the world over maintain traditional social relations while simultaneously engaging in capitalist markets and producing goods for subsistence purposes. I attempted to show that the increasingly simplistic official definition of the concept of koha, which emptied it of any real content, stemmed from the division of Maori fisheries into customary and commercial spheres. I further argued that the definition of customary activity as the absence of monetary transactions is not consistent with either international legal decisions, or with the social reality of small-scale Maori fishers. These fishers operate in mixed economies, sometimes moral, sometimes capitalist, and exchange fish in much the same manner - sometimes in order to achieve a balance and sometimes for profit.

The distinction made between commercial and non-commercial fishing denies their essential integration in the practices of small-scale fishers across time and space and further, this development stands in direct opposition to the most fundamental tenet of anthropology, that all social institutions are interconnected. Simply put, culture cannot be divorced from economics.

The best way to describe the present situation is that there is an interregnum characterised by unresolved conflicts of interest. The regulations are in place but they are not rigidly applied. The question then arises as to why Government has not taken measures to ensure compliance? Three possible explanations can be postulated. The first concerns the level of Maori resistance. The opposition of Maori to the regulations is in historic keeping with the reaction of Maori to forces seeking to undermine their economic, social and cultural relations by the imposition of more impersonal systems. The genesis of this conflict can be found in the attempt to achieve a universal commodification of all social, economic and cultural relations. As noted by Scott (1976) and Thompson (1991), in such situations tradition is used in a dynamic way to challenge the erosion of a way of life and is employed to counter new class and property systems which lead to greater inequalities of wealth and loss of control over subsistence resources. It is in this sense that the traditional practice of koha was employed as a process by which Maori fishers could oppose the imposition of new regimes which had led to a loss of control over their fisheries resources. ${ }^{31}$ 
Secondly, the artificial distinction made between commercial and customary Maori fishing, removed as it is from social reality, was arguably doomed to failure. Thirdly, P. Sinclair's observation regarding the commercial distinctions between inshore and deep-sea fisheries also provides elucidation, given that

...the uncertain, seasonal and small-scale nature of inshore fishing leaves domestic commodity producers free from the direct competition of large-scale capitalists for whom this type of investment is unattractive...

(1985:144).

This might help explain why the inshore regulations are not applied rigorously or suffer from benign neglect - the commercial giants are simply not interested. The only reason for Government action is to gain populist support. Interestingly, in the most recent controversy surrounding Maori claims to the foreshore and seabed, commercial giants were very interested (in for instance the commercial value of harbours, aqua-farming and so on) and populist sentiment was vehemently opposed to Maori claims. In this instance the government acted speedily and forcefully to impose controversial and arguably draconic legislation in contravention of Maori property rights.

NOTES

1 In keeping with the editorial policy of Sites no macrons for elongated vowels have been used.

2 See: 'The making of the English Working Class', 1968, Penguin.

3 My use of the terms 'peasant' and 'petty commodity' is strictly theoretical, although I would like to thank one of the reviewers of this paper for drawing attention to the terms' other connotations.

4 See note 3 .

5 For instance the Fisheries Act 1983, the Fisheries Amendment Act 1986, the Maori Fisheries Act 1989. See Fairgray 1985, 1986; Habib 1985; Law Commission 1989; Hawkey, 1994. 
6 For a comprehensive review of the commercial aspect of the 1992 Act see Durie 2005: 109-128.

7 The Maori negotiating body was called Papae/Taumata 2.

8 The existence of two customary fisheries regulations, one for the South Island and one for the North Island of New Zealand, stems primarily from a Treaty Settlement package negotiated between the major South Island iwi, Ngai Tahu, and the Crown. This package included customary fisheries regulations. There are no major differences between the two sets of regulations.

9 Maori are also able, like all New Zealanders, to catch to recreational limits under the Amateur Fishing Regulations.

10 Personal email from a Senior Policy Analyst, Treaty of Waitangi Fisheries Commission 14th June 2004.

11 The 2003 amendment is more extensively prohibitive than that enacted in 1998 which stated that no species of fish, aquatic life or seaweed may be taken pursuant to R27 Fisheries (Amateur Fishing) Regulations 1986 where the taking is commercial in any way or is for pecuniary gain or trade.

12 Personal email from a Senior Policy Analyst, Te Ohu Kaimoana (токм), 14th June 2004.

13 This is all of Pattersons Inlet, excluding Ulva Island marine reserve, on Stewart Island

14 Personal email from the Ministry of Fisheries, 5th of October 2004.

15 Personal email from a Policy Analyst, Fisheries Management, Ministry of Fisheries, 4th of October, 2004.

16 Personal email from the National Manager, Non Commercial Fishing, Ministry of Fisheries 4th of October, 2004.

17 Personal email from the National Manager, Non Commercial Fishing, Ministry of Fisheries 5th of October, 2004

18 ...A customary right is not just for a Hui, it's for survival everyday (John Ututaonga, 1998, Transcript of Pacific Banks, Customary Fishing Rights, 13/12/98). 
1928 November 1997 in District Court Gisbourne, CRN701600609/570.

20 A reviewer of this article commented 'What has been represented here as koha is not really koha at all as it involves utu - that makes it hokohoko (barter).

21 Ibid

2223 November 1998, in District Court, Kaikohe, CRN8027006005-6.

23 Ibid

24 Ibid

25 Ibid

26 CRN8004044264, 65.

27 Ibid

28 Ibid

$29 R v$ Van Der Peet [1996] ICHRL 61 (21 August 1996).

30 Other government departments explicitly accept that koha may include the exchange of money. A 1998 Inland Revenue Pamphlet: 'Payments and gifts in the Maori community' outlines situations where koha is taxable and where it is non-taxable. In the first case, koha is subject to taxation where 'it is a payment for services'; and it is not subject to taxation, where 'it is an unconditional gift [and] ...gives no direct benefit to the givers'. Both situations may clearly involve money.

31 As noted by Mason Durie, support for Hikuwai was at best partial, 'There was an outcry from Maori and the Government alike, both incensed that custom was being used to justify what seemed to be a flagrant breach of the law and a lucrative commercial operation...many Maori were offended that customary practice could be appropriated to suit the occasion...' (2005:129-130). Durie does however recognise that Hikuwai was responding to the dire economic circumstances of Northland Maori who had been left bereft by the Quota Management System. 


\section{REFERENCES}

Appadurai, A. 1986 'Introduction: Commodities and the politics of value', in A. Appadurai (ed) The Social Life of Things: Commodities in Cultural Perspective, Cambridge: Cambridge University Press: 3-63.

Cook, S. and Binford, L. 1990 Obliging Need: Rural Petty Industry in Mexican Capitalism, Austin: University of Texas Press.

Durie, M. 2005 Nga Tai Matatu: Tides of Maori Endurance, Melbourne and Auckland: Oxford University Press.

Fairgray, J. 1985 'ITQ implications study: First report, Northland fishing communities 1984', FMP Series No. 13. Fisheries Management Division, MAF, Wellington.

Fairgray, J. 1986 'ITQ implications study: Second report, community issues', FMP Series, No. 20. Fisheries Management Division, MAF, Wellington.

Habib, G. 1985 'Maori involvement in the New Zealand fishing industry. Report for the Maori Economic Development Commission', Southpac Fisheries Consultants, Auckland.

Hawkey, D. 1994 'Property rights, ITQs, and the slice of the fish pie: An appraisal of fishery culture and conflict in the Northland region', Working Papers in Economics, No 17, Department of Economics, University of Auckland.

Law Commission, 1989 'The Treaty of Waitangi and Maori Fisheries. Mataitai: Nga Tikanga Maori me te Tiriti o Waitangi', Preliminary Paper No 9. Wellington, New Zealand.

Long, N. and Richardson, P. 1978 'Informal sector, petty commodity production and the social relations of small-scale enterprise', in J. Clammer (ed) The New Economic Anthropology, New York: St Martins Press: 176-209.

McCormack, F. 1997 'Cultural Implications of the Resource Management Act', unpublished MA Thesis, University of Auckland.

McHugh, P. 1992 'Sealords and sharks: The Maori fisheries agreement', New Zealand Law Journal, 10:354-58. 
Ministry of Fisheries, (nd) 'Customary Fishing Rights and Rules' http://www.fish. govt.nz/customary/introduction.html

Moser, C. 1978 'Informal sector or petty commodity production: Dualism or dependence in urban development', World Development, 6(9):1041-1064.

Salazar, C. 1996 A Sentimental Economy, Commodity and Community in Rural Ireland, Providence: Berghahn Books.

Scott, J. 1976 The Moral Economy of the Peasant, New Haven: Yale University Press.

Sinclair, P. R. 1985 'From Traps to Draggers: Domestic Commodity Production in Northwest Newfoundland, 1850-1982', Social and Economic Papers No. 31, Institute of Social and Economic Research, St. John's: Memorial University of Newfoundland.

Thompson, E. P. 1968 The Making of the English Working Class, Harmondsworth: Penguin.

Thompson, E. P. 1991 Customs in Common, London: The Merlin Press.

Waitangi Tribunal, 2004 'Report on the Crown's Foreshore and Seabed Policy' (Wai 1071), Wellington: New Zealand Department of Justice.

Williams, T and Robinson D. 2004 'Social capital and philanthropy in Maori society', The International Journal of Not-for-Profit Law, 6(2) http://www. icnl.org/JOURNAL/vol6iss2/ar_williams.htm 